\title{
The Credit CARD Act of 2009: What Did Banks Do?
}

\author{
Vikram Jambulapati and Joanna Stavins
}

\begin{abstract}
The Credit CARD Act of 2009 was intended to prevent practices in the credit card industry that lawmakers viewed as deceptive and abusive. Among other changes, the Act restricted issuers' account closure policies, eliminated certain fees, and made it more difficult for issuers to change terms on credit card plans. Critics of the Act argued that because of the long lag between approval and implementation of the law, issuing banks would be able to take preemptive actions that might disadvantage cardholders before the law could take effect. Using credit bureau data as well as individual data from a survey of U.S. consumers, we test whether banks closed consumers' credit card accounts or otherwise restricted access to credit just before the enactment of the CARD Act. Because the period prior to the enactment of the CARD Act coincided with the financial crisis and recession, causality in this case is particularly difficult to establish. We find evidence that a higher fraction of credit card accounts were closed following the Federal Reserve Board's adoption of its credit card rules. However, we do not find evidence that banks closed credit card accounts or deteriorated terms of credit card plans at a higher rate between the time when the CARD Act was signed and when its provisions became law.
\end{abstract}

\section{JEL Codes: D14, D18, G28}

When this paper was written Vikram Jambulapati was a research assistant at the Federal Reserve Bank of Boston. He is now a Ph.D. candidate at MIT Sloan School of Management. Joanna Stavins is a senior economist and policy advisor in the research department of the Federal Reserve Bank of Boston. Both are members of the Consumer Payments Research Center. Their email addresses are vikjam@mit.edu and joanna.stavins@bos.frb.org, respectively.

We are grateful to Pattie Allouise, John Driscoll, Chris Foote, Scott Fulford, Ashley Mahoney, Ali Ozdagli, Joe Peek, Scott Schuh, Oz Shy, Robert Triest, and Christina Wang for helpful comments.

The views expressed in this brief are the authors' and do not necessarily reflect the official position of the Federal Reserve Bank of Boston or the Federal Reserve System.

This paper, which may be revised, is available on the web site of the Federal Reserve Bank of Boston at http://www.bostonfed.org/economic/ppdp/index.htm. 


\section{Introduction}

The Credit CARD Act of $2009^{1}$ introduced a series of reforms intended to prevent practices in the credit card industry that lawmakers viewed as deceptive and abusive. The Act was signed into law in May 2009, and the majority of its provisions became effective nine months after the passage of the law -in February 2010. However, the signing of the law was preceded by a long series of events that made the changes almost certain long before May 2009. In particular, at the end of 2008 the Federal Reserve Board adopted final rules pertaining to credit cards to protect consumers from unfair acts or practices with respect to consumer credit card accounts. The effective date for the Fed rules was several months after the CARD Act was to become effective. Therefore, the CARD Act superseded the Board's proposed rules, but by 2008 - and possibly as early as 2007-issuing banks knew that the rules governing disclosure and rate increases were about to change.

Banks do not appear to have closed accounts at a higher rate between May 2009, when the CARD Act was signed, and when most of its provisions took effect in February 2010, based on our analysis of aggregate U.S. data and data from a monthly survey of U.S. consumers, the Consumer Finance Monthly (CFM). However, banks do appear to have changed terms on credit card plans during this period, especially by lowering credit limits. Among the CFM survey respondents whose bank accounts were closed during that period, account holders were much more likely to close their own credit card accounts than to have them closed by their card issuers.

Yet banks may have taken action in anticipation of the passing of the CARD Act long before it was enacted into law. The evidence shows that a higher fraction of credit card accounts were closed immediately following adoption by the Federal Reserve Board of its rules concerning credit cards than in the period between the law's enactment and its taking effect. This earlier period coincides with the recession, making it difficult to identify clearly whether the main cause of these closures was the economic downturn or preemptive action in anticipation of the new legislation.

Significant restrictions placed on credit card issuers by the Act include advance notice of any interest rate increase, a limit on the fees charged for late payments, and improvements in the transparency and consistency of billing cycles. In particular, consumers must be notified in

${ }^{1}$ Officially known as the Credit Card Accountability, Responsibility and Disclosure Act of 2009 (Credit CARD Act of 2009, H.R. 627). 
writing at least 45 days in advance before the issuer raises the interest rate on their credit card account (exceptions include promotional and variable rates). Advance notice also must precede other significant changes, and consumers must be offered the right to close their accounts in response to those changes. ${ }^{2}$

Because the Act made it more difficult for the issuers to change the terms on their credit card plans and the law did not come into effect until nine months after its passage, issuers may have made some changes in advance of implementation of the law, and even in advance of the Fed rules. Once issuers knew that the credit card policy changes were about to become law, they may have raised interest rates or lowered credit limits before the law took effect. Anecdotal evidence suggests that credit card companies raised rates and fees and closed unprofitable accounts in advance of the legislation (for example, Connelly 2010).

We are interested in whether banks restricted credit supply to consumers beyond what was warranted by economic conditions. ${ }^{3}$ The question we are investigating is as follows: Did banks move preemptively prior to the enactment of the CARD Act by closing credit card accounts, lowering credit limits, or otherwise deteriorating terms on credit card plans? ${ }^{4}$ The Federal Reserve’s October 2009 “Senior Loan Officer Opinion Survey on Bank Lending Practices” included a special question on banks' expectations with regard to the effects of the Credit CARD Act. As a result of the CARD Act, banks reported that they "expect to tighten or have already tightened” many terms on credit card loans for both prime and nonprime borrowers. ${ }^{5}$ However, previous Senior Loan Officer Opinion Surveys conducted earlier in 2009 and in the second half of 2008 revealed that banks started tightening credit card lending standards and lowering credit limits on new and existing credit card accounts long before the CARD Act was signed into law. ${ }^{6}$ We are interested in whether this tightening was due to something other than economic conditions.

\footnotetext{
${ }^{2}$ Details of the bill are provided online at http:/thomas.loc.gov/cgi-bin/bdquery/z?d111:HR00627:@@@.

${ }^{3}$ There is a broad literature linking exogenous shocks with the price and supply of bank loans (for example, Bernanke and Blinder 1988, Peek and Rosengren 1997, 2000).

${ }^{4}$ Consumers who would otherwise have closed their accounts may have kept them open in anticipation of the future benefits of the CARD Act. However, it is more likely that banks acted preemptively to curtail credit supply.

${ }^{5}$ http://www.federalreserve.gov/boarddocs/snloansurvey/200911/.

${ }^{6}$ Although the CARD Act does not focus on credit limits, some of its provisions are related to credit limits: If a person has co-signed on a credit card account (typically for a minor), then the credit card issuer cannot change the limit without written consent from the co-signer; cardholders must now opt-in for the ability to exceed their credit limit; and annual fees and application fees are capped at 25 percent of the initial credit limit.
} 
Because the period just prior to the Act coincided with the recession, it is difficult to separate the effect of the recession from that of the CARD Act. As a result of the recession, aggregate consumption and therefore demand for credit dropped, while at the same time the legislation changed the supply of credit and the terms of credit card plans. We therefore use individual consumer data to take advantage of cross-sectional differences among cardholders to try to separate the supply and demand effects. There is evidence that a higher fraction of credit card accounts were closed and credit card lending was tightened right after the Federal Reserve Board adopted its rules pertaining to credit cards. However, we do not find any evidence that banks made such changes just before the CARD Act became effective.

Several studies have examined the effects of the Credit CARD Act. Bar-Gill and Bubb (2012) compared terms of credit card plans just prior to the enactment of CARD Act rules in February 2010 to those after the final set of CARD Act rules became law in August 2010. Pew (2011) compared credit card application disclosures from July 2009 and March 2010 and found some evidence of a decline in practices that regulators intended to curb, but also some evidence of an increase in new fees, in penalty interest rates, and in cash advance fees.

A few studies examined the determinants of credit card limits independently of the Credit CARD Act. Dey and Mumy (2005) used a cross-section household survey to estimate approved credit limits. Gross and Souleles (2002a) used administrative data from credit card issuing banks and found that credit scores, debt levels, and account age affect credit card limits. Although credit card account closures have not been estimated directly, Campbell, Martinez-Jerez, and Tufano (2012) estimated the determinants of bank account closures. They find that in addition to socioeconomic characteristics, social variables, such as crime and voter turnout, and prevalence of alternative financial institutions, such as payday lenders, predict involuntary bank account closures. Related to credit card account closures, a number of papers have analyzed default risks for credit cards. These include papers that adjust for selection bias (Greene 2007), account for consumer relationships to issuing banks (Agarwal, Chomsisengphet, Liu, and Souleles 2010), and use duration models (Gross and Souleles 2002b). To the best of our knowledge, this is the first paper analyzing the changes introduced by issuing banks between the time the Act was signed into law and the time when it became effective.

Section 2 describes the timing of the events leading up to the enactment of the CARD Act. Section 3 describes changes observed in aggregate U.S. data, while Section 4 considers evidence 
based on individual data from the Equifax credit bureau and separate data from the Consumer Finance Monthly, a monthly survey of U.S. consumers. Section 5 provides regression results from an analysis of the survey data, and Section 6 concludes.

\section{Timing of the events}

The CARD Act was a result of a long-standing sentiment in the Congress that credit card issuers' abusive and unfair practices, such as hidden fees and unannounced interest rate increases, were hurting cardholders and should be prevented. Both the Congress and the Federal Reserve were involved in the various stages leading to this legislation. Table 1 provides a timeline of the passage of the legislation. In May 2007, the Federal Reserve Board (the Board) published proposed revisions to the credit card disclosures required under the Truth in Lending Act regulations (titled Notice of Proposed Rule under the Truth in Lending Act). In February 2008, Chairman Bernanke testified before Congress that the Board was planning to use authority under the Federal Trade Commission Act (FTC Act) to propose rules prohibiting unfair or deceptive credit card practices. In May 2008, the Board issued for public comment proposed rules to prohibit unfair practices regarding credit cards and overdraft services. Among other provisions, the rules would protect consumers from unexpected increases in the rate charged on pre-existing credit card balances. The proposed rules would change Regulation AA (Unfair or Deceptive Acts or Practices), Regulation Z (Truth in Lending), and Regulation DD (Truth in Savings). On December 18, 2008, the Board adopted final rules pertaining to credit cards, published in January 2009, to protect consumers from unfair acts or practices with respect to consumer credit card accounts (74 FR 5498, January 2009 FTC Act Rule). The effective date for the Board rules was July 1, 2010-several months after the CARD Act was to become effective. Therefore, the CARD Act superseded the Board's proposed rules, but the issuing banks knew as early as 2007,

and certainly by 2008 , that the rules governing disclosure and rate increases were about to change.

In the $110^{\text {th }}$ Congress, the Credit Cardholders' Bill of Rights was introduced in the House of Representatives by Representative Carolyn Maloney, the chair of the House Financial Services Committee's Subcommittee on Financial Institutions and Consumer Credit. The bill passed, but was never given a vote in the Senate. The bill was then reintroduced in the $111^{\text {th }}$ United States Congress as H.R. 627 and passed by the House on April 30, 2009. The Senate 
passed an amended version on May 19, and the Credit Card Accountability, Responsibility and Disclosure Act of 2009 (CARD Act) was signed into law by President Barack Obama on May 22, 2009.

The CARD Act primarily amends the Truth in Lending Act and establishes a number of new substantive and disclosure requirements to establish fair and transparent practices pertaining to open-ended consumer credit plans. Several of the provisions of the CARD Act are similar to provisions in the Board's January 2009 Regulation Z and FTC Act Rules, while other portions of the CARD Act address practices or mandate disclosures that were not addressed in the Board's rules. The requirements of the CARD Act that pertain to credit cards took effect in three stages: some provisions took effect on August 20, 2009 (90 days after enactment of the CARD Act), the majority of the provisions, including those regarding interest rate increases, took effect on February 22, 2010 (nine months after enactment), and the final two provisions became effective on August 22, 2010 (15 months after enactment).

Even though the Board rules were adopted in December 2008 and the CARD Act was not signed into law until May 2009, the predecessors to the CARD Act began as early as 2007, so issuing banks could have anticipated the rules at that time. In addition, the economic recession preceding those events may have induced lending banks to tighten their credit card policies even earlier. A Federal Reserve survey of lenders taken in October 2008 revealed that 60 percent of surveyed banks tightened their credit card lending, either by lowering credit card limits or by closing credit card accounts. ${ }^{7}$ It is not clear, however, whether the tightening was caused by the anticipated regulatory changes or by the deterioration in economic conditions. In particular, the fourth quarter of 2008 marked the height of the financial market panic, after Lehman's bankruptcy, the entry of the government-sponsored enterprises into conservatorship, and the bailout of AIG. It is therefore very hard to identify to what extent the panic may have caused the account closings.

\section{Aggregate trends in the credit card market}

The number of credit card accounts in the United States rose until 2002 and then remained flat until 2008 (Figures 1). At the same time, the total credit limit available to

\footnotetext{
${ }^{7}$ See http://www.nytimes.com/2008/11/04/business/economy/04fed.html?_r=1 and http://www.wzzm13.com/news/watercooler/story.aspx?storyid=100820.
} 
households rose steadily (Figure 2). Beginning in 2008, the number of credit card accounts and the total credit limit available declined sharply, reversing the trend of the past decade. While the number of accounts declined by about a quarter, the total credit limit declined by about a third, so the average credit card limit per account dropped (Figure 3). The vertical lines in the figures represent the major events related to the CARD Act: adoption of the Board rules in December 2008 (line A), the signing of the CARD Act in May 2009 (line B), and the taking effect of the majority of the CARD Act rules in February 2010 (line C). Because the Fed rules were proposed in 2007, evidence of any changes may be observable even earlier than December 2008. In fact, as Figures 1 and 2 show, both the number of accounts and the total credit limit started declining even before the Board rules were adopted (line A).

The decline in the aggregate credit limit available to consumers has also been observed by others, such as FICO (2011) and TransUnion (2011). By the third quarter of 2011, the number of accounts had fallen below the level observed in 2000, while the total credit limit had declined to levels observed in 2001. The CARD Act was passed during this period of decline, and both measures stabilized after the majority of the provisions had taken effect. Aggregate credit card balances started declining in 2008 as well, before the CARD Act was signed into law and even shortly before the Board adopted its credit card rules. Still, the average credit card balance per account continued to rise until after the CARD Act was signed (Figure 3).

Separating demand and supply factors is always difficult, but because the period between the passage and the implementation of the CARD Act immediately followed the recession in the United States, ${ }^{8}$ it is especially difficult to identify the cause of the changes in the credit market. The steepest decline in the number of accounts took place before the CARD Act was signed into law, suggesting that the decline was-at least to some extent-caused by the recession. On the demand side, the economic recession likely caused a drop in demand for credit card spending and the closing of credit card accounts. Consumers may have reduced their spending because of the recession and revolvers may have wanted to curtail their debt. ${ }^{9}$ On the supply side, the regulatory changes and the financial crisis made banks more reluctant to extend credit and

\footnotetext{
${ }^{8}$ According to the NBER, the recession started in December 2007 and ended in June 2009 (Available at http: //www.nber.org/cycles.html).

${ }^{9}$ Javelin Strategy and Research (2010) attributes the decline in credit card use during this period to the recent recession, and respondents to the Federal Reserve's quarterly Senior Loan Officer Opinion Survey on Bank Lending Practices reported a drop in demand for credit card loans as early as 2008.
} 
induced lenders to curtail the amount of credit card lending. In addition, the cost of borrowing increased during that period. As shown in Figure 4, the average annual percentage rate (APR) on credit cards declined to a low of 12 percent during the recession and rose by almost 2 percentage points before the CARD Act, peaking at just over 14 percent right before many of the Act's provisions took place. As Figure 4 indicates, the average yield on checking account and money market deposits—a measure approximating banks' cost of funds—did not increase during that period. Even though the rise in credit card interest rates leading up to the passage and implementation of the CARD Act is consistent with the hypothesis that issuers raised interest rates prior to the Act taking effect, several other factors - such as increased risk of lendingcould explain the rising interest rates.

\section{Individual consumer evidence: Credit bureau and survey data}

\subsection{Credit bureau evidence}

To help isolate the effects of the CARD Act on the terms of credit card plans, we examined individual-level credit bureau data from Equifax containing data on credit card accounts, credit limits, balances held, and repayment behavior from a 5-percent sample of all U.S. consumers who have a credit history with Equifax. ${ }^{10}$ The Equifax data also provide each consumer's risk score, a measure of the probability of default closely correlated with (but computed separately from) the FICO score. Unfortunately, the only demographic variable in the Equifax data is the respondent's age. Nevertheless, individual consumer data allow us to analyze account closings for consumers with the same credit card balances and delinquency status over time, thereby distinguishing issuers' account closing decisions based on those factors from account closing decisions based on the anticipated CARD Act.

Jimenez, et al. (2012) address the difficulty of disentangling the supply of credit from the demand for credit during times of low economic growth, when both the supply of and the demand for bank loans may decline, by combining individual loan data with specific bank-month effects to control for each bank's balance sheet strength. Unfortunately, our data do not allow us to control for issuer-specific fixed effects, because we lack issuing bank identifying information.

The Equifax data do not include information on who closed the account-the account holder or the issuer-but only on the number of credit card accounts held by each consumer in a

\footnotetext{
${ }^{10}$ Lee and van der Klaauw (2010) provide a detailed description of the data.
} 
given quarter. We created a dummy variable $C_{i t}$ equal to 1 if consumer $i$ had at least one credit card account closed in quarter $t$ compared with the previous quarter. From the number of credit card accounts consumer $i$ held in quarter $t\left(A_{i t}\right)$, we subtracted the number of accounts held by consumer $i$ in quarter $t-1\left(A_{i, t-1}\right)$ and subtracted the number of new accounts consumer $i$ opened in quarter $t\left(O_{i t}\right)$ :

$$
C_{i t}=\left\{\begin{array}{c}
1 \text { if } A_{i t}-A_{i, t-1}-O_{i t}<0 \\
0 \text { otherwise }
\end{array} .\right.
$$

The dummy variable $C_{i t}$ is equal to 1 if a consumer had fewer accounts in period $t$, indicating that at least one of his accounts was closed-either by the consumer or by his card issuer. Figure 5 shows five data series represented by five different lines. Based on the Equifax data, the figure shows the fraction of consumers who had at least one account closed during the current quarter (bottom line), during the previous six months (second line), nine months (third line), or at any time during the previous 12 months (top line). As would be expected, the longer the time period, the higher is the fraction of consumers who had at least one account closed. In addition to the Equifax data, the figure shows the fraction of consumers who reported having their credit card account closed during the previous 12 months in the Consumer Finance Monthly (CFM) survey. ${ }^{11}$ Two things can be noted here: (1) the fraction of consumers who had their account closed rose sharply in 2008-early 2009, around the time of the adoption of the Board's credit card rules, and (2) the fraction of consumers who reported having their credit card account closed in the CFM survey is consistent with the fraction found in the Equifax data. The CFM account closing rate is lower than the 12-month Equifax closing rate and is closer to the 9-month Equifax closing rate, but the discrepancy could arise from the fact that the CFM survey is selfreported and, as with any self-reported survey, it may suffer from the usual survey issues, such as poor recall and/or not wanting to admit to account closings.

$\Delta A_{i t}$ is the change in the number of accounts consumer $i$ held at time $t$ relative to time $t-1$. If $\Delta A_{i t}>0$, the number of accounts increased, while if $\Delta A_{i t}<0$, the number dropped. Figure 6 plots the average change in the number of credit card accounts from the previous quarter by the

\footnotetext{
${ }^{11}$ The Consumer Finance Monthly survey is conducted by the Ohio State University. The credit card accounts could have been closed either by the cardholder or by his/her bank.
} 
Equifax risk score, while Figure 7 plots the change by age cohort. There was a noticeable drop in the number of accounts held around the time of the adoption of the Board of Governors' rules, regardless of the cardholder's risk score or age, although the decline was more pronounced for those over the age of 35 than for the younger cohort (possibly because older consumers start with more credit cards). The finding that the number of accounts declined similarly across all credit score classes indicates a reaction to an external shock, although it is not clear what type of shock would cause such a uniform transition.

Using the Equifax data, we estimate how the probability of having a credit card account closed changed with time, while controlling for credit card activity and debt status. We estimate $C_{i t}$ - a dummy variable indicating whether the number of credit card accounts held by consumer $i$ decreased between $t-1$ and $t$ ) - as a function of consumer i's credit card debt and delinquency status, as well as quarterly dummy variables:

$$
C_{i t}=\boldsymbol{\delta}^{\prime} \boldsymbol{D}_{t}+\boldsymbol{\omega}^{\prime} \boldsymbol{D P P D} \boldsymbol{D}_{i, t-1}+\gamma \mathrm{Cur}_{i, t-1}+\beta \mathrm{Bal}_{i, t-1}+\varepsilon_{i t},
$$

where $\boldsymbol{D}_{t}$ is a vector of quarter dummies, $\boldsymbol{D P P} \boldsymbol{D}_{i, t-1}$ is a set of variables indicating the number of credit card accounts 30,60, 90, and 120 days past due at time $t-1, \operatorname{Cur}_{i, t-1}$ is the number of credit card accounts reported active by the issuing bank in the past three months as of time $t-1$, and $B a l_{i, t-1}$ is the dollar value of credit card debt. ${ }^{12}$ We use Equifax data from the second quarter of 2006 to the end of 2012. Table 2 shows summary statistics on the Equifax variables used in the model. As the table shows, 12 percent of the sample had at least one account closed during that period. The regression results are discussed below.

\subsection{Consumer survey evidence}

Although the Equifax data do not provide any information on who closed the credit card accounts-whether the consumer voluntarily closed his account or whether his issuing bank closed it - the two scenarios have different causes and implications. If accounts were closed in anticipation of the upcoming CARD Act reform, the closings are more likely to have been involuntary account closings initiated by the banks, because consumers had no reason to close

\footnotetext{
${ }^{12}$ Including the risk score on the right-hand side did not change the regression results.
} 
their own accounts just because of the pending credit card reforms (recall that the CARD Act was designed to protect and help consumers, not to hurt them). However, some cardholders may have decided to close their accounts in reaction to some changes in their credit card plans that were made by their banks in anticipation of the card reform. Therefore, either voluntary or involuntary closures may be related to the reforms. Account closings related to the recession may have been requested by the cardholder as part of his household deleveraging, ${ }^{13}$ although a bank may also have decided to close an inactive account when a cardholder stopped using his card because of a loss in income.

To try to isolate the two types of account closures, and to examine whether consumers were more likely to have their credit card accounts closed and/or the terms of their credit card plans changed prior to the CARD Act, the Consumer Payments Research Center (CPRC) of the Federal Reserve Bank of Boston added a series of questions to the Consumer Finance Monthly (CFM) survey. The CFM survey has been administered since 2005 by the Center for Human Resource Research at the Ohio State University. The CFM is conducted each month with a sample of 300 to 500 households selected through random digit dialing. Responses are then stratified according to the Current Population Survey based on income, race, age, and home ownership. The resulting dataset provides a series of nationally representative monthly crosssections of the U.S. population. The survey asks a wide range of questions related to household finances, including all categories of debt, income, assets, and savings. The detailed questions about consumer credit card holding and borrowing are designed to resemble the detailed questions included in the Survey of Consumer Finances. ${ }^{14}$

Our questions were added to the CFM between March 2010 and December 2011 and included questions about the preceding 12 months, thus covering the period just after the Federal Reserve regulations were approved. The added questions included changes in employment status and hours worked, both for the respondent and for his or her spouse, in addition to many detailed questions about credit card account closures and changes to the respondent's credit card plans. The partial list of added questions and the means of the variables based on those added questions are shown in Table 3.

\footnotetext{
${ }^{13}$ A consumer might decide to close his account in the recession in order to reduce his credit card debt, but that reason is unrelated to the CARD Act.

${ }^{14}$ For additional information about the CFM data, see http://www.chrr.ohio-state.edu/content/surveys/cfm/cfm.html.
} 
In addition to the overall means, we separated the sample into two periods: up to and including February 2011, and after February 2011. We did this because we want to test whether changes that occurred prior to February 2010 differed significantly from changes that took place after February 2010, and we were able to do this because we had asked respondents about changes to their credit card plans during the preceding 12 months. However, because we ask about the entire period of the preceding 12 months, the two periods may overlap. For example, a survey conducted in May 2011 asks about the entire 12-month period between May 2010 and May 2011, so it may not be possible to completely separate the pre-February 2010 period from the post-February 2010 period.

Because we want to assess whether and to what extent credit card account closure was related to the recession, we added several questions about respondents' employment status. However, fewer than 50 percent of the CFM sample reported being employed at the time of the survey. Because this number is substantially lower than the employed share in the U.S. data, ${ }^{15}$ the CFM sample does not seem to be representative of the U.S. population. Nevertheless, because we can control for socio-demographic variables, our micro data approach may still be useful to assess whether consumers report changes in the way issuing banks altered the terms on credit card plans. For example, if the data undersample consumers in a certain age or income group, we can control for those attributes to test what affected the likelihood that those consumers had their credit card accounts closed or terms changed.

The vast majority of people who were employed at the time of the survey had been employed during the entire preceding 12 months (92 percent), but 13 percent of them had had their work hours cut during that time. The numbers were almost identical for the respondents' spouses. Household income remained the same as a year earlier for about half the sample and decreased for about a quarter of the sample. Below, we test whether these employment or income changes had a significant effect on the likelihood of the respondent's bank changing the terms on credit card plans.

Table 3 shows the percentage of respondents who had their credit card account closed by their issuing bank or who closed it themselves, and the major reasons for the closures. We are primarily interested in survey responses up to February 2011, when the preceding 12 months

\footnotetext{
${ }^{15}$ According to the Bureau of Labor Statistics (BLS), the U.S. employment/population ratio during this period was approximately 58 percent, see http://data.bls.gov/timeseries/LNS12300000.
} 
included the period of time before the CARD Act was effective but after it was passed and therefore certain to become law. In response to questions about credit card account closures, only 4.5 percent of the respondents said that a bank had closed their credit card account during the previous 12 months. The main reason for account closing was an inactive account. In contrast, 14.9 percent of the respondents said that they closed one or more of their credit card accounts themselves. Among those who closed their own accounts, only 14.9 percent cited a change in terms of credit card plans as the main reason, and the most common change triggering a customer's request for closure was an increase in the annual interest rate. Therefore, the CFM dataset provides some support for the hypothesis that card issuing banks may have raised interest rates preemptively prior to the rule changes affecting their ability to change interest rates at will. Yet, there is little evidence that banks closed accounts at a higher rate during the period shortly before the CARD Act became effective. However, as the Equifax data shown in Figure 5 demonstrate, the peak in account closures took place prior to the period covered in the CFM survey questions.

Figure 8 shows the percentage of CFM survey respondents reporting at least one account closure in the previous 12 months, aggregated to a quarterly level to reduce noise from small sample sizes in monthly data. The majority closed their own account. The two vertical lines represent 12 months after the signing and 12 months after the implementation of the Credit CARD Act, respectively (the survey question asks about the preceding 12 months). The data do not show any significant shifts in consumers' reports of account closures by banks prior to the taking effect of the CARD Act, but the CFM data do not go back far enough to assess changes that occurred following the Federal Reserve Board's policy announcements in 2008. Other data sources confirm the CFM findings and show a similar breakdown of account closings: the majority of accounts that were reported by consumers as having been closed during that period were closed by the cardholders, not by their issuing banks (Figure 9).

Few differences in responses between the pre-February 2011 and the post-February 2011 responses were statistically significant, as indicated by asterisks in the last column of Table 3. Even though there were no significant differences in the rate of account closings, banks were significantly more likely to change the terms on credit card plans before February 2011, especially to lower the credit limit. Comparing the two time periods, there was a large and significant decline in the fraction of respondents reporting changes in their credit limits. At the 
same time, as an answer to the "Because the terms changed, decided to ..." question, there was a large and significant decline in the fraction of respondents saying that they were going to spend less on credit cards and less overall. It is not clear, however, whether consumers intended to spend less in response to the changes in their credit limits. The summary statistics based on the CFM survey do not yield conclusive results about account closures or changes in terms on credit card plans between the time when the CARD Act was signed into law and when it was implemented.

\section{Regression results}

\subsection{Card account closure using Equifax data}

Table 4 presents the results of estimating equation (2) using OLS, probit, and logit. The results do not vary qualitatively among the three models. The estimated coefficients on the quarter dummy variables show how account closures changed over time, controlling for each cardholder's credit card debt and delinquency. Figure 10 plots the estimated effect of time on the probability of account closure, measured as the estimated coefficients on the quarter dummies from column (1) of Table 4 plus the constant term. Because the model used here is a linear probability model, the time dummy coefficients represent the probability of a consumer's experiencing a decline in the number of accounts held over a period of three months, after controlling for the consumer's credit card balances and delinquency status. As Figure 10 shows, the fraction of consumers with fewer accounts rose sharply starting in the third quarter of 2008 and peaked in early 2009-long before the CARD Act was signed into law, but around the time of the Federal Reserve Board's adoption of the final rules on credit cards in December $2008 .{ }^{16}$ While the Equifax data do not support the hypothesis that credit card issuers closed accounts specifically in anticipation of the CARD Act becoming effective, the results are consistent with the hypothesis that the increase in credit card account closures is correlated with the adoption of the Federal Reserve credit card policies.

\footnotetext{
${ }^{16}$ The fraction of consumers with fewer accounts rises sharply even when controlling for each consumer's age and FICO score.
} 


\subsection{Card account closure using consumer survey data}

To control for individual cardholders' income and demographic attributes, we used the CFM data to estimate probit regressions with the following dependent variables: (1) a dummy variable equal to 1 if a consumer's account was closed either by a bank or by the consumer, (2) a dummy variable equal to 1 if a bank closed the respondent's credit card account, (3) a dummy variable equal to 1 if a respondent closed his credit card account, and (4) a dummy variable equal to 1 if a bank changed the terms of the respondent's credit card accounts. We control for losing a job, a decline in work hours, a decline in income, making a late payment, education, gender, race, and quarterly time dummy variables.

The results are reported in Table 5. No variables were significant in predicting consumerinitiated closures. Losing a job or making a late payment during the previous year were significant predictors of bank decisions to close an account. Several variables were significant predictors of changes in the terms on credit card plans: losing a job, having hours cut, and making a late payment all raised the probability of having terms changed. Respondents with at least some higher education and those who experienced an increase in household income also witnessed a change in terms, although the terms may have changed in their favor (for example, an increase in the credit limit). The quarter indicators show significant differences between the excluded period (2010:Q1-2010:Q2) and other periods for changes in terms on credit card plans, confirming that banks were more likely to change terms during the earlier part of the period covered by the sample questions. ${ }^{17}$ No time pattern was found for account closures. It is possible that consumers are more likely to underreport card account closings by banks than the other measures discussed here, because of embarrassment or other emotional issues, while the change in the terms of credit cards is a more objective measure, producing more reliable results.

\section{Conclusion}

We investigate whether credit card issuers closed credit card accounts, lowered credit limits, or otherwise deteriorated terms on credit card plans between the time when the CARD Act was signed in May 2009 and when most of its provisions became law in February 2010.

\footnotetext{
${ }^{17}$ Including credit card debt in the regressions did not alter the quarterly dummy coefficients. Although credit card debt had a significant and positive effect on account closure in all three regressions, the coefficients were very small and thus not economically significant. We do not report those results here, because the credit card debt included in the data is as of time $t$, while the account closure variables include the period of the 12 months up to time $t$.
} 
Based on aggregate U.S. data and on data from a monthly survey of U.S. consumers, we do not find evidence that banks closed accounts at a higher rate, but we do find evidence that banks changed terms on credit card plans, especially by lowering credit limits between the time when the CARD Act was signed into law and when it took effect. Data from the Consumer Finance Monthly survey show that respondents were much more likely to close their own credit card accounts than to have their accounts closed by the issuers. This pattern is likely attributable more to the economic recession than to the regulatory changes.

However, credit card issuers anticipated the passing of the CARD Act long before the Act was signed, and so the period studied here may not be long enough to capture the relevant changes. In particular, there is evidence that a higher fraction of credit card accounts were closed immediately following adoption by the Federal Reserve Board of its rules pertaining to credit cards in late 2008 than in May 2009 through February 2010. Because the pre-CARD Act period coincided with the recession, it is difficult to isolate the cause of any changes that took place in the credit card market during that time. 


\section{References}

Agarwal, S., S. Chomsisengphet, C. Liu, and N. Souleles. (2010). "Benefits of Relationship Banking: Evidence from Consumer Credit arkets,” Working Paper Series WP-2010-05, Federal Reserve Bank of Chicago.

Bar-Gill, Oren, and Ryan Bubb. 2012. "Credit Card Pricing: The Card Act and Beyond.” Cornell Law Review 97(5): 1-52.

Bernanke, B. S. and A. S. Blinder. 1988. “Credit, Money, and Aggregate Demand,” American Economic Review 78: 435-439.

Campbell, D., F. A. Martinez-Jerez, and P. Tufano. (2012). "Bouncing Out of the Banking System: An Empirical Analysis of Involuntary Bank Account Closures.” Journal of Banking and Finance 36 (4): 1224-1235.

Connelly, Ellen. 2010. "Mixed Blessing: Credit Card Reform May Shock Some.” ABC News, February 20. Available at: http://abcnews.go.com/Business/wireStory?id=9906985.

Dey, S. and G. Mumy. (2005), Determinants of Borrowing Limits on Credit Cards, Bank of Canada Working Paper 2005-7.

FICO. 2011. “How Much Is U.S. Credit Behavior Changing?” FICO White Paper No. 56.

Greene, W. H. (2007). “A Statistical Model for Credit Scoring.” In D. Hensher \& S. Jones (Eds.), Credit Risk: Quantitative Methods and Analysis. Cambridge University Press.

Gross, D. B. and N.S. Souleles. (2002a). "Do Liquidity Constraints and Interest Rates Matter for Consumer Behavior? Evidence from Credit Card Data.” The Quarterly Journal of Economics 117 (1): 149-185.

Gross, D. B. and N.S. Souleles. (2002b). "An Empirical Analysis of Personal Bankruptcy and Delinquency," Review of Financial Studies 15(1): 319-347.

Javelin Strategy and Research. 2010. "Payment Card Issuer Strategies: The Rise of the Cautious Consumer.” Javelin Research Library.

Jiménez, Gabriel, Steven Ongena, José-Luis Peydró, and Jesús Saurina. 2012. “Credit Supply and Monetary Policy: Identifying the Bank Balance-Sheet Channel with Loan Applications,” American Economic Review 102(5): 2301-2326.

Lee, Donghoon, and Wilbert van der Klaauw. 2010. “An Introduction to the FRBNY Consumer Credit Panel.” New York Federal Reserve Staff Reports No. 479. Available at http://www.newyorkfed.org/research/staff reports/sr479.html. 
Peek, J. and E.S. Rosengren. 2000. "Collateral Damage: Effects of the Japanese Bank Crisis on Real Activity in the United States,” American Economic Review 90: 30-45.

Peek, J. and E.S. Rosengren. 1997. "The International Transmission of Financial Shocks: The Case of Japan,” American Economic Review 87(4): 495-505.

Pew (2011). "Two Steps Forward: After the Credit Card Act, Credit Cards Are Safer and More Transparent But Challenges Remain.” Pew Research Reports.

TransUnion. 2011. “A Perspective on Credit Card Usage and Consumer Performance.” Presented at the CARD Act Conference hosted by the Consumer Financial Protection Bureau (CFPB) in Washington D.C. 


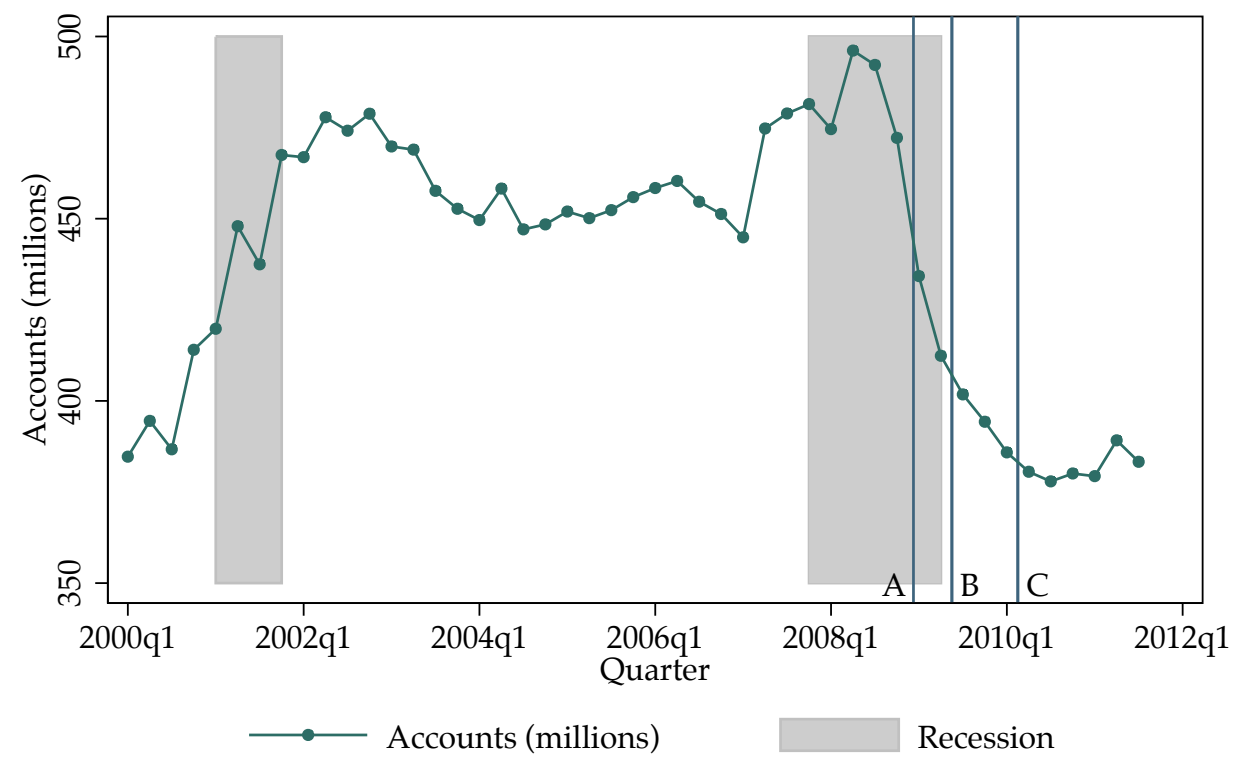

A = Adoption of the Board rules (Dec. 2008), B = Signing of the CARD Act (May 2009), $\mathrm{C}=\mathrm{CARD}$ Act becomes effective (Feb. 2010)

Source: NY Federal Reserve Consumer Credit Panel / Equifax

Figure 1: Number of credit card accounts in the U.S.

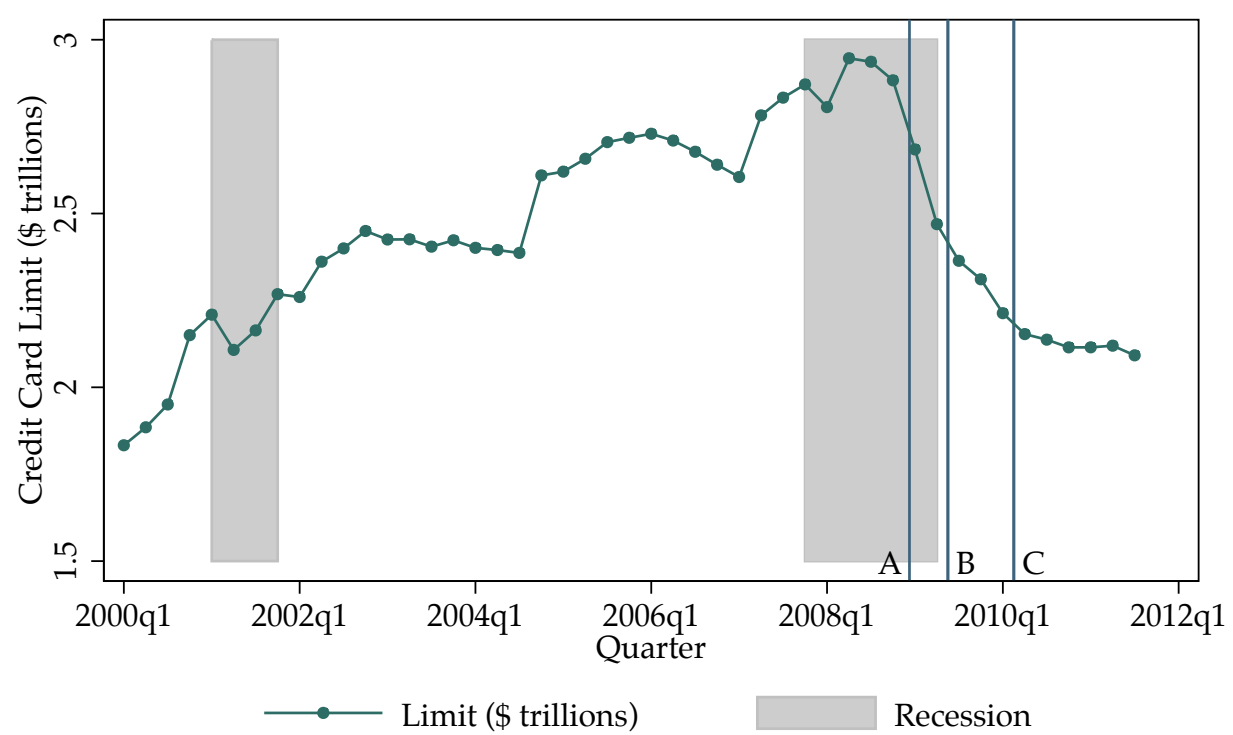

A = Adoption of the Board rules (Dec. 2008), B = Signing of the CARD Act (May 2009),

$\mathrm{C}=$ CARD Act becomes effective (Feb. 2010)

Source: NY Federal Reserve Consumer Credit Panel / Equifax

Inflation adjusted values (normalized to $2000 \mathrm{q} 4$ )

Figure 2: Total credit card limit in the U.S. 


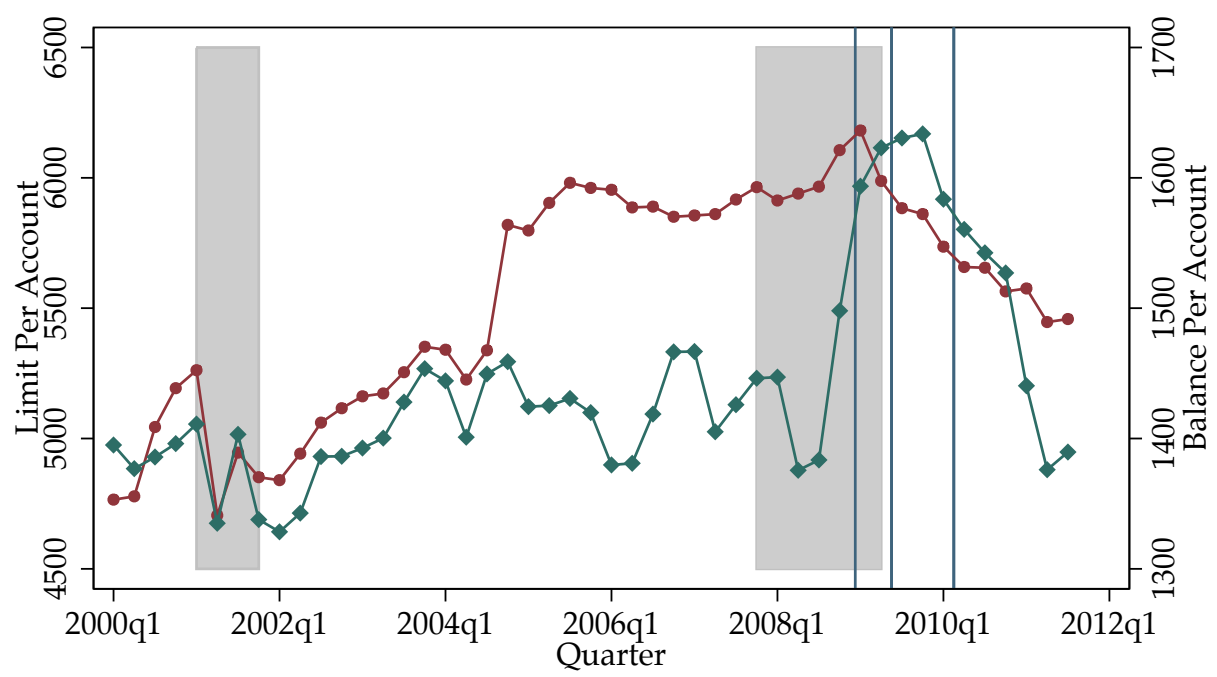

$\longrightarrow$ Limit Per Account $\longrightarrow$ Balance Per Account $\square$ Recession

A = Adoption of the Board rules (Dec. 2008), B = Signing of the CARD Act (May 2009),

$\mathrm{C}=$ CARD Act becomes effective (Feb. 2010)

Source: NY Federal Reserve Consumer Credit Panel / Equifax

Inflation adjusted values (normalized to $2000 q 4$ )

Figure 3: Average credit card limit and average balance per account in the U.S.

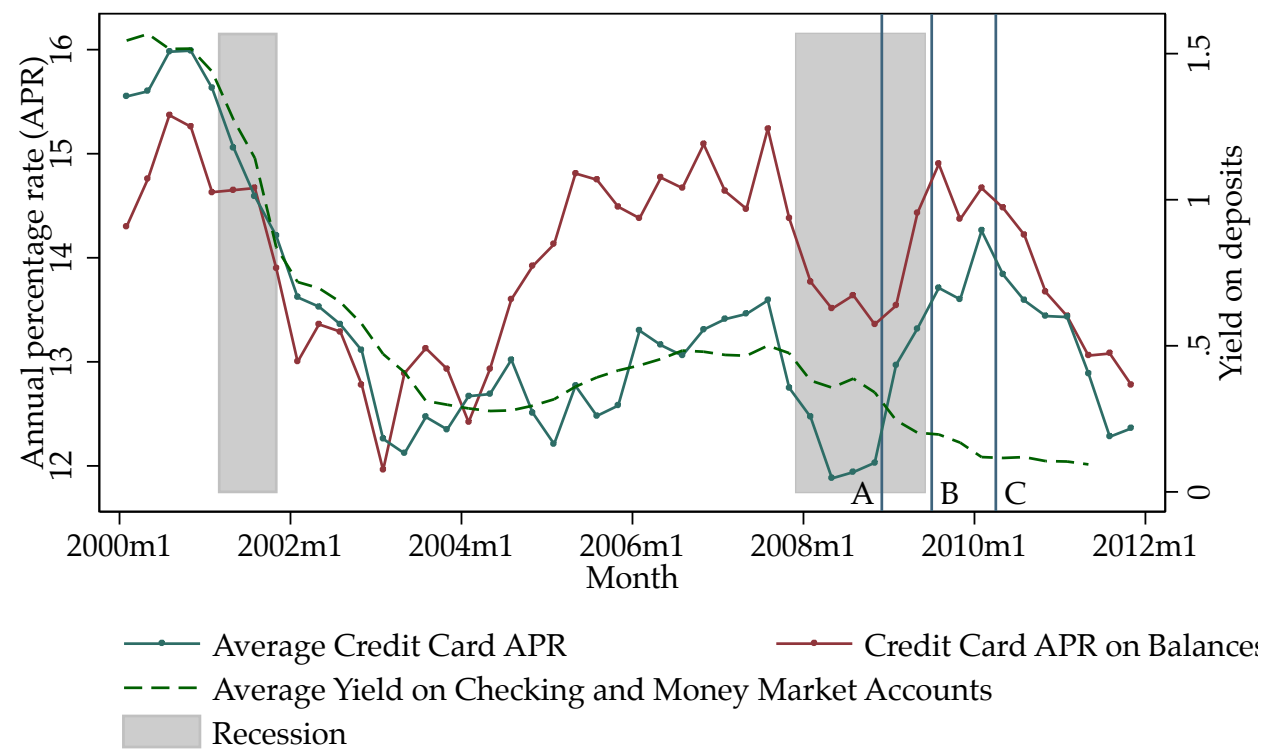

A = Adoption of the Board rules (Dec. 2008), B = Signing of the CARD Act (May 2009),

$\mathrm{C}=$ CARD Act becomes effective (Feb. 2010)

Sources: Board of Governors, not seasonally adjusted / Bankrate

Figure 4: Interest rates for consumers, and yield on checking and money market accounts 


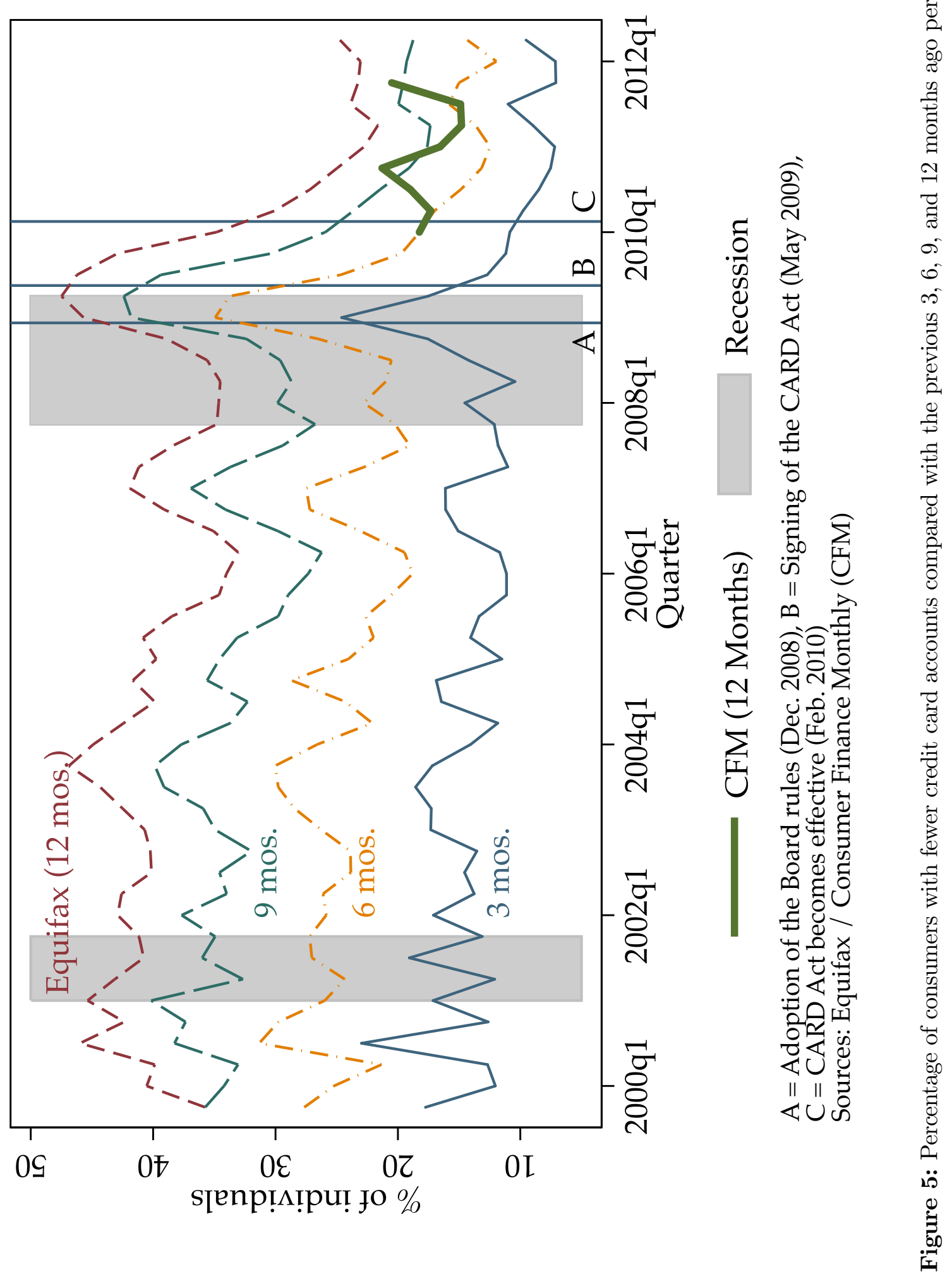




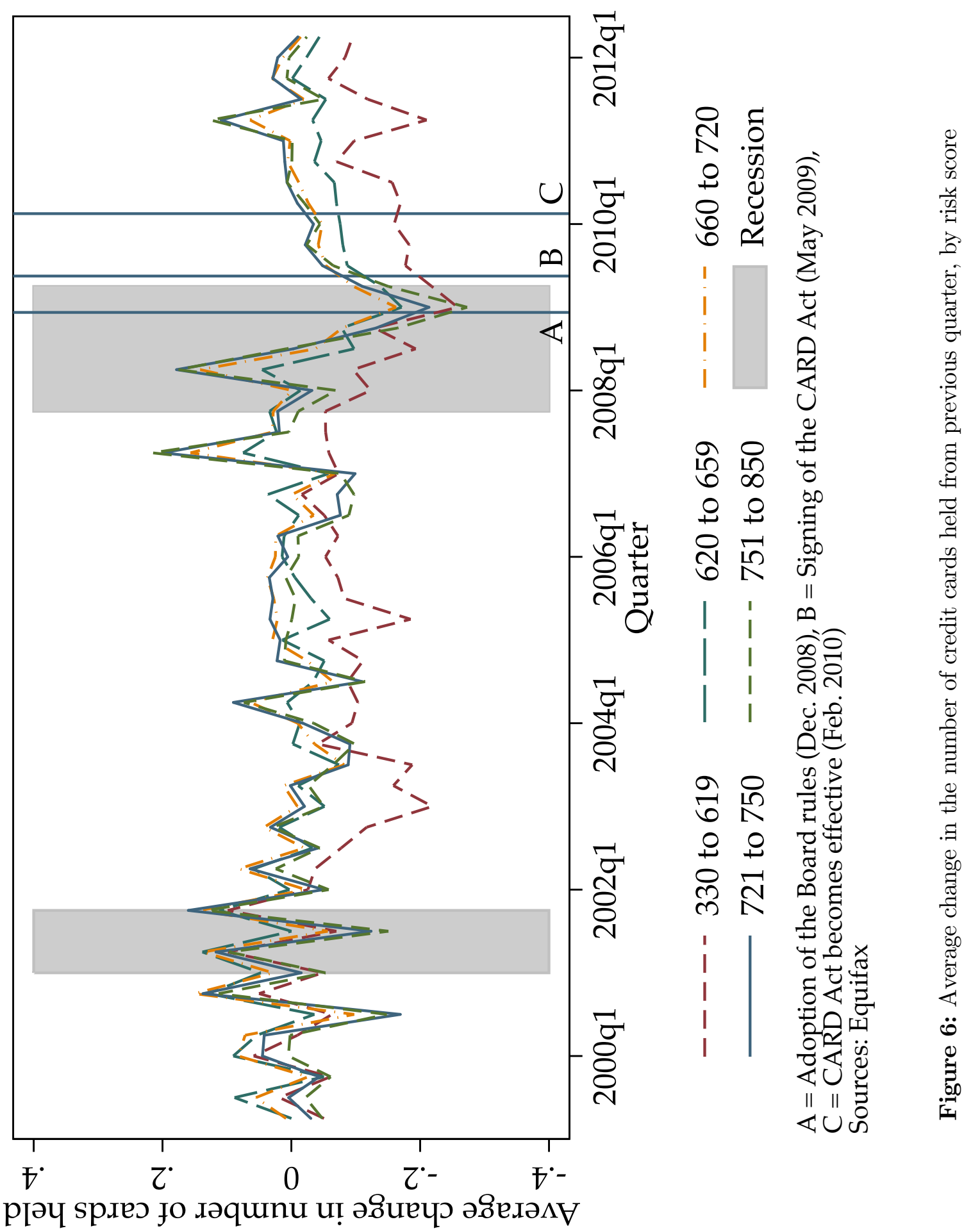




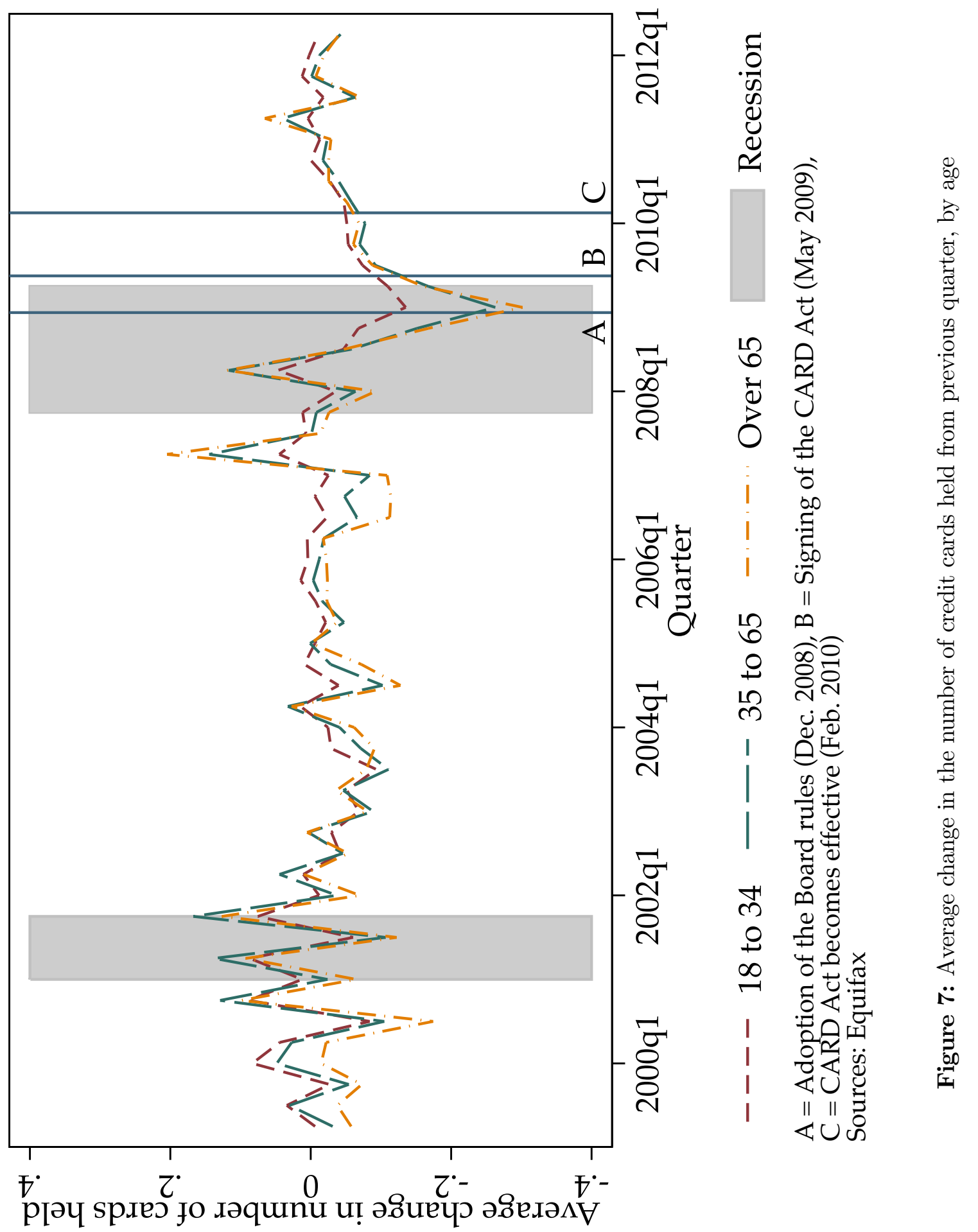




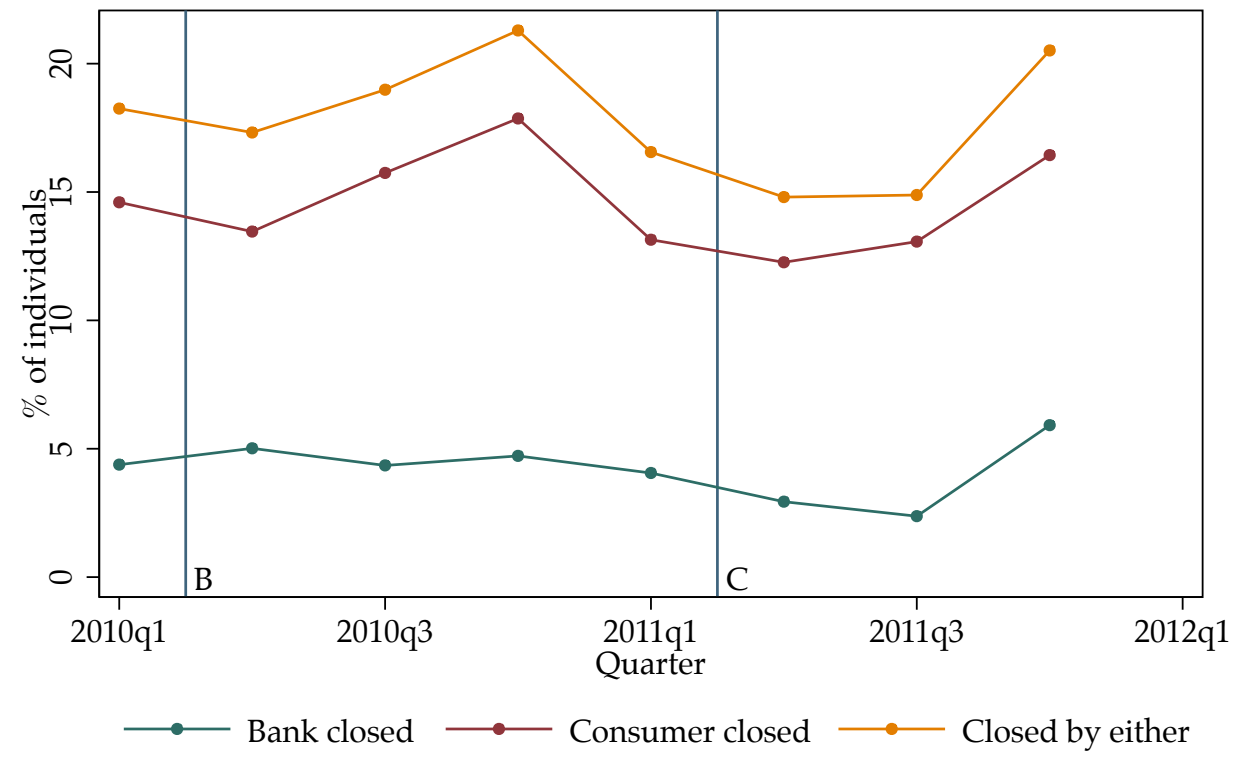

$B=12$ Months After Signing of the CARD Act (May 2009),

$\mathrm{C}=12$ Months After CARD Act becomes effective (Feb. 2010)

Source: Consumer Finance Monthly (CFM)

Figure 8: Percentage of individuals with at least one account closure in past 12 months

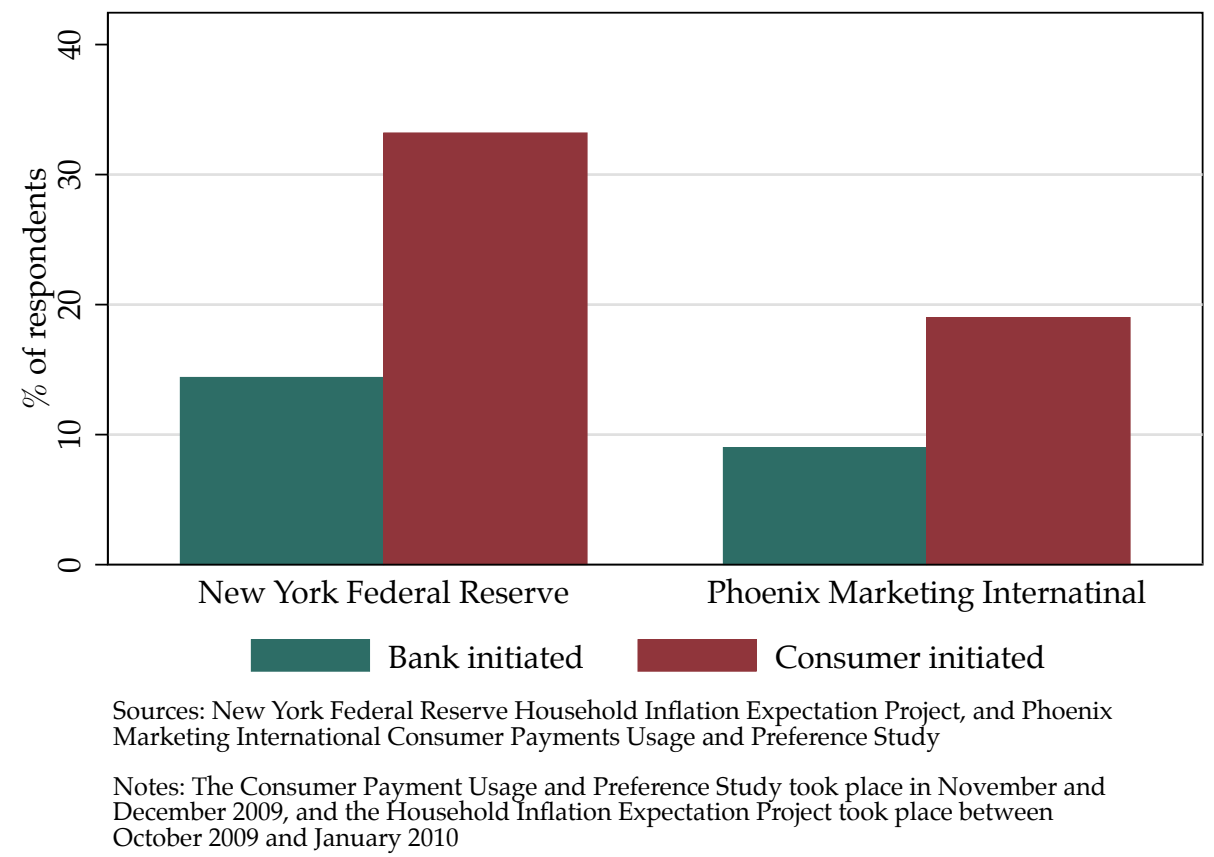

Figure 9: Credit card account closures in past 12 months by survey source 


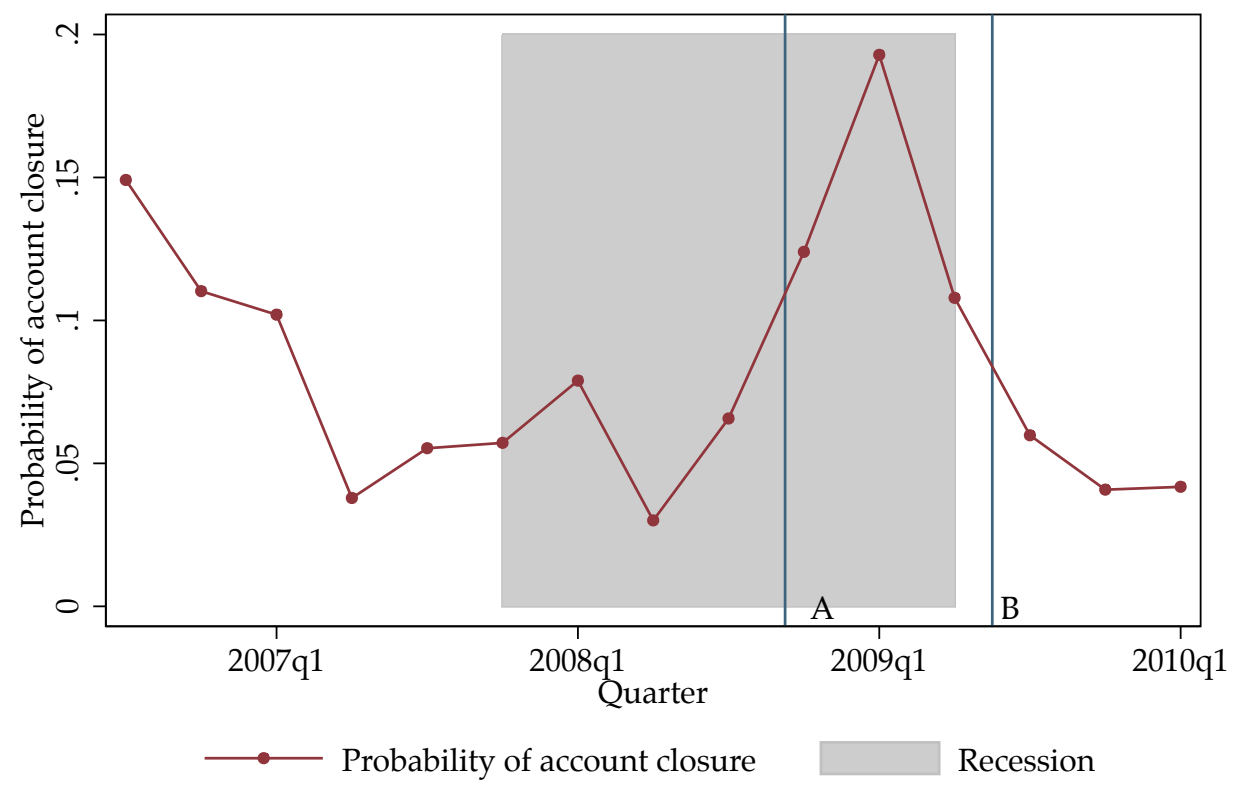

A = Adoption of the Board rules (Dec. 2008), B = Signing of the CARD Act (May 2009), Sources: Equifax

Figure 10: Estimated coefficients on quarterly dummies from Equation 2: $C_{i t}=\delta^{\prime} D_{t}+\omega^{\prime} D P D_{i, t-1}+\gamma C u r_{i, t-1}+$ $\beta B a l_{i, t-1}+\epsilon_{i t}$, a linear probability regression of account closure, controlling for the number of credit cards in delinquency, active credit cards, and dollar value of credit card debt. The quarterly dummy coefficients represent the probability of account closure in a given quarter, when controlling for credit card delinquency, the number of credit cards, and dollar value of credit card debt. 
Table 1: Timeline of the Credit CARD Act

\begin{tabular}{|c|c|}
\hline Date of Event & Event Description \\
\hline May 23, 2007 & The Federal Reserve proposes new disclosure rules for credit cards. \\
\hline February 7, 2008 & $\begin{array}{l}\text { Representative Carolyn Maloney introduces the Credit Cardholders' Bill of } \\
\text { Rights Act in the U.S. House of Representatives (H.R. 5244). }\end{array}$ \\
\hline February 27, 2008 & $\begin{array}{l}\text { Chairman Ben Bernanke testifies before Congress that the Federal Reserve } \\
\text { plans to propose new rules regulating credit card issuer practices. }\end{array}$ \\
\hline May 2, 2008 & $\begin{array}{l}\text { The Federal Reserve proposes rules to limit credit card practices and overdraft } \\
\text { fees. }\end{array}$ \\
\hline September 23, 2008 & $\begin{array}{l}\text { The House passes the bill introduced in May 2007, but the Senate fails to } \\
\text { take a vote on the measure. }\end{array}$ \\
\hline December 18, 2008 & $\begin{array}{l}\text { The Federal Reserve approves several rules similar to provisions in the Credit } \\
\text { Cardholders' Bill of Rights Act. }\end{array}$ \\
\hline January 22, 2009 & Rep. Maloney introduces the Credit CARD Act in the House (H.R. 627). \\
\hline April 30, 2009 & The Act passes in the House with a margin of 287 votes. \\
\hline May 19, 2009 & The Act passes in the Senate with a margin of 85 votes. \\
\hline May 22, 2009 & President Obama signs the Act into law. \\
\hline February 22,2010 & $\begin{array}{l}\text { Major portions of the Act become effective, including the } 45 \text {-day notice of } \\
\text { interest rate or fee increases and elimination of unfair billing practices. }\end{array}$ \\
\hline August 22,2010 & Final provisions of the CARD Act go into effect \\
\hline
\end{tabular}

Sources: Dates for the Credit Cardholders' Bill of Rights are available online at http://thomas.loc.gov/cgi-bin/bdquery/z? d110:HR05244:@@@R. Dates for the Credit Card Act are available online at http://thomas.loc.gov/cgi-bin/bdquery/z?d111: HR00627:@@@R. The Federal Reserve initial proposal on new disclosure rules can be viewed online at http://www. federalreserve.gov/newsevents/press/bcreg/20070523a.htm. Subsequent proposals from the Federal Reserve can be viewed online at http://www.federalreserve.gov/newsevents/press/bcreg/20080502a.htm. Chairman Bernanke's testimony before Congress is available online at http://www.federalreserve.gov/newsevents/testimony/bernanke20080227a.htm. Summary of the implementation can be viewed online at http://www.federalreserve.gov/newsevents/press/bcreg/20100112a.htm

Table 2: Summary of selected Equifax variables (2006q2 to 2012q4)

\begin{tabular}{lrrrr}
\hline Variable & Mean & Std. Dev. & Min. & Max. \\
\hline Account closure & 0.12 & 0.33 & 0 & 1 \\
Age & 49.90 & 18.68 & 18 & 111 \\
Equifax Risk Score & 692.19 & 107.63 & 291 & 842 \\
\# of credit card accounts 30 days past due & 0.01 & 0.14 & 0 & 9 \\
\# of credit card accounts 60 days past due & 0.01 & 0.12 & 0 & 10 \\
\# of credit card accounts 90 days past due & 0.01 & 0.10 & 0 & 13 \\
\# of credit card accounts 120 days past due & 0.02 & 0.18 & 0 & 17 \\
\# of credit card accounts severe deragatory & 0.09 & 0.40 & 0 & 19 \\
\# of credit card accounts bankrupt & 0.01 & 0.11 & 0 & 9 \\
\# of credit cards reported active & 1.62 & 1.48 & 0 & 26 \\
Value of credit card balance $(\$)$ & 5469.25 & 12723.25 & 0 & 2331594 \\
\hline Source: Equix & & & & \\
\hline
\end{tabular}

Source: Equifax 
Table 3: Summary of selected Ohio State CFM variables (March 2010 to December 2011)

\begin{tabular}{|c|c|c|c|c|c|}
\hline \multirow[b]{2}{*}{ Variable } & \multirow[b]{2}{*}{$\begin{array}{c}\text { Number of } \\
\text { of Obs. }\end{array}$} & \multicolumn{3}{|c|}{ Percent of respondents } & \multirow[b]{2}{*}{$\begin{array}{l}\text { Difference } \\
\text { Post - Pre }\end{array}$} \\
\hline & & $\begin{array}{l}\text { Entire } \\
\text { period }\end{array}$ & $\begin{array}{c}\text { Pre } \\
\text { Feb. } 2011\end{array}$ & $\begin{array}{c}\text { Post } \\
\text { Feb. } 2011\end{array}$ & \\
\hline Employed & 5380 & 45.9 & 43.7 & 49.0 & $5.3^{* * *}$ \\
\hline \multicolumn{6}{|l|}{ If currently employed } \\
\hline employed past 12 months & 2301 & 92.2 & 91.6 & 92.9 & 1.3 \\
\hline hours cut & 2459 & 13.2 & 13.0 & 13.5 & 0.5 \\
\hline \multicolumn{6}{|l|}{ If currently unemployed } \\
\hline employed at all past 12 months & 2903 & 9.5 & 9.4 & 9.5 & 0.1 \\
\hline Spouse employed & 3488 & 59.4 & 56.5 & 63.1 & $6.6^{* * *}$ \\
\hline If spouse currently unemployed & 1414 & 8.1 & 7.9 & 8.3 & 0.4 \\
\hline \multicolumn{6}{|l|}{ Compared to a year ago, household income } \\
\hline Decreased significantly & 5317 & 10.3 & 10.5 & 10.0 & -0.5 \\
\hline Decreased somewhat & 5317 & 14.4 & 14.4 & 14.5 & 0.1 \\
\hline More or less the same & 5317 & 55.2 & 55.8 & 54.4 & -1.4 \\
\hline Increased somewhat & 5317 & 17.1 & 16.4 & 18.1 & $1.7^{*}$ \\
\hline Increased significantly & 5317 & 3.0 & 2.9 & 3.0 & 0.1 \\
\hline Bank closed credit card account & 4240 & 4.2 & 4.5 & 3.7 & -0.8 \\
\hline \multicolumn{6}{|l|}{ Reasons bank closed account } \\
\hline Did not use & 177 & 41.8 & 45.5 & 35.8 & -9.7 \\
\hline Behind on payments & 177 & 19.8 & 19.1 & 20.9 & 1.8 \\
\hline Over the limit & 177 & 2.3 & 3.6 & 0.0 & -3.6 \\
\hline Bank company closed & 177 & 2.3 & 1.8 & 3.0 & 1.2 \\
\hline Other reasons & 177 & 33.9 & 30.0 & 40.3 & 10.3 \\
\hline Consumer closed credit card account & 4235 & 14.6 & 14.9 & 14.0 & -0.9 \\
\hline \multicolumn{6}{|l|}{ Reasons consumer closed account } \\
\hline Did not use & 612 & 32.0 & 31.7 & 32.5 & 0.8 \\
\hline Charged too much & 612 & 8.0 & 8.0 & 8.0 & 0.0 \\
\hline Worried would charge too much & 612 & 2.5 & 3.3 & 1.2 & $-2.1^{*}$ \\
\hline Bank changed terms (mainly interest rate) & 612 & 13.4 & 14.9 & 11.2 & -3.7 \\
\hline Other reasons & 612 & 44.1 & 42.1 & 47.0 & 4.9 \\
\hline Bank changed terms on any credit card & 3685 & 29.1 & 31.9 & 25.3 & $-6.6^{* * *}$ \\
\hline \multicolumn{6}{|l|}{ Credit card terms that changed } \\
\hline Interest rate & 937 & 66.3 & 67.7 & 63.8 & -3.9 \\
\hline Annual fee & 998 & 15.0 & 15.4 & 14.4 & -1.0 \\
\hline Over the limit fee & 815 & 42.5 & 40.2 & 46.3 & $6.1^{*}$ \\
\hline Credit limit & 1028 & 24.7 & 27.4 & 20.2 & $-7.2^{* *}$ \\
\hline Payment timing & 930 & 16.3 & 16.0 & 16.9 & 0.9 \\
\hline \multicolumn{6}{|l|}{ Because terms change decided to } \\
\hline Repay balance & 1056 & 27.4 & 29.1 & 24.4 & -4.7 \\
\hline Switch credit cards & 1066 & 11.5 & 11.0 & 12.5 & 1.5 \\
\hline Switch payment methods & 1064 & 10.0 & 10.0 & 10.0 & 0.0 \\
\hline Spend less on credit cards & 1066 & 45.8 & 48.3 & 41.4 & $-6.9^{* *}$ \\
\hline Spend less overall & 1064 & 50.7 & 53.8 & 45.3 & $-8.5^{* * *}$ \\
\hline
\end{tabular}

Significance values for testing equality of the percentages between pre and post passage of the Credit CARD Act are denoted by ${ }^{*} p<0.10,{ }^{* *} p<0.05,{ }^{* * *} p<0.01$

Bold lines indicate values of particular interest.

Source: Ohio State CFM 
Table 4: Predicting credit card account closures

\begin{tabular}{|c|c|c|c|}
\hline & $\begin{array}{c}(1) \\
\text { OLS }\end{array}$ & $\begin{array}{c}(2) \\
\text { Probit }\end{array}$ & $\begin{array}{c}(3) \\
\text { Logit }\end{array}$ \\
\hline $2006 q 3$ & $0.042^{* * *}$ & $0.041^{* * *}$ & $0.041^{* * *}$ \\
\hline $2006 q 4$ & $0.055^{* * *}$ & $0.053^{* * *}$ & $0.053^{* * *}$ \\
\hline $2007 q 1$ & $0.048^{* * *}$ & $0.046^{* * *}$ & $0.046^{* * *}$ \\
\hline $2007 q 2$ & $-0.012^{* * *}$ & $-0.012^{* * *}$ & $-0.012^{* * *}$ \\
\hline $2007 q 3$ & 0.003 & 0.003 & 0.003 \\
\hline $2007 q 4$ & $0.006^{*}$ & $0.006^{*}$ & $0.006^{*}$ \\
\hline $2008 q 1$ & $0.025^{* * *}$ & $0.024^{* * *}$ & $0.024^{* * *}$ \\
\hline $2008 \mathrm{q} 2$ & $-0.022^{* * *}$ & $-0.021^{* * *}$ & $-0.021^{* * *}$ \\
\hline $2008 \mathrm{q} 3$ & $0.013^{* * *}$ & $0.012^{* * *}$ & $0.012^{* * *}$ \\
\hline $2008 \mathrm{q} 4$ & $0.067^{* * *}$ & $0.065^{* * *}$ & $0.065^{* * *}$ \\
\hline $2009 q 1$ & $0.138^{* * *}$ & $0.133^{* * *}$ & $0.133^{* * *}$ \\
\hline $2009 q 2$ & $0.055^{* * *}$ & $0.053^{* * *}$ & $0.053^{* * *}$ \\
\hline $2009 \mathrm{q} 3$ & $0.007^{* *}$ & $0.007^{* *}$ & $0.007^{* *}$ \\
\hline $2009 q 4$ & $-0.011^{* * *}$ & $-0.011^{* * *}$ & $-0.011^{* * *}$ \\
\hline 2010q1 & $-0.010^{* * *}$ & $-0.010^{* * *}$ & $-0.010^{* * *}$ \\
\hline $2010 \mathrm{q} 2$ & $-0.026^{* * *}$ & $-0.026^{* * *}$ & $-0.026^{* * *}$ \\
\hline $2010 \mathrm{q} 3$ & $-0.038^{* * *}$ & $-0.038^{* * *}$ & $-0.038^{* * *}$ \\
\hline $2010 \mathrm{q} 4$ & $-0.041^{* * *}$ & $-0.041^{* * *}$ & $-0.041^{* * *}$ \\
\hline 2011q1 & $-0.045^{* * *}$ & $-0.045^{* * *}$ & $-0.045^{* * *}$ \\
\hline $2011 q 2$ & $-0.049^{* * *}$ & $-0.049^{* * *}$ & $-0.049^{* * *}$ \\
\hline 2011q3 & $-0.005^{*}$ & $-0.005^{*}$ & $-0.005^{*}$ \\
\hline $2011 q 4$ & $-0.043^{* * *}$ & $-0.043^{* * *}$ & $-0.043^{* * *}$ \\
\hline $2012 q 1$ & $-0.046^{* * *}$ & $-0.045^{* * *}$ & $-0.045^{* * *}$ \\
\hline $2012 q 2$ & $-0.019^{* * *}$ & $-0.019^{* * *}$ & $-0.019^{* * *}$ \\
\hline $2012 q 3$ & $-0.035^{* * *}$ & $-0.034^{* * *}$ & $-0.034^{* * *}$ \\
\hline $2012 q 4$ & $-0.034^{* * *}$ & $-0.033^{* * *}$ & $-0.033^{* * *}$ \\
\hline Age & $0.001^{* * *}$ & $0.001^{* * *}$ & $0.001^{* * *}$ \\
\hline Equifax Risk Score & $0.000^{* * *}$ & $0.000^{* * *}$ & $0.000^{* * *}$ \\
\hline 30 days past due & $0.031^{* * *}$ & $0.022^{* * *}$ & $0.022^{* * *}$ \\
\hline 60 days past due & $0.038^{* * *}$ & $0.025^{* * *}$ & $0.025^{* * *}$ \\
\hline 90 days past due & $0.041^{* * *}$ & $0.025^{* * *}$ & $0.025^{* * *}$ \\
\hline 120 days past due & $0.133^{* * *}$ & $0.081^{* * *}$ & $0.081^{* * *}$ \\
\hline Bankrupt card & $0.188^{* * *}$ & $0.117^{* * *}$ & $0.117^{* * *}$ \\
\hline Active cards & $0.012^{* * *}$ & $0.011^{* * *}$ & $0.011^{* * *}$ \\
\hline Balance (thousands) & $0.000^{* * *}$ & $0.000^{* * *}$ & $0.000^{* * *}$ \\
\hline
\end{tabular}

Dependent variable: account closure indicator.

The excluded quarter indicator is 2006q2.

Marginal effects have been reported for probit and logit estimates.

${ }^{*} p<0.05,{ }^{* *} p<0.01,{ }^{* * *} p<0.001$

Source: Authors' calculations using Equifax data 
Table 5: Predicting bank and consumer initiated account closures and change in terms

\begin{tabular}{lcccc}
\hline & Any closed $=1$ & Bank closed $=1$ & Consumer closed $=1$ & Terms changed $=1$ \\
\hline Lost job & $0.041^{* *}$ & $0.021^{* *}$ & 0.025 & $0.069^{* * *}$ \\
Hours cut & $(0.020)$ & $(0.011)$ & $(0.018$ & $(0.025)$ \\
Female & 0.027 & 0.018 & 0.013 & $0.065^{* *}$ \\
& $(0.021)$ & $(0.011)$ & $(0.019)$ & $(0.027)$ \\
Black & -0.020 & -0.001 & -0.009 & 0.008 \\
& $(0.012)$ & $(0.006)$ & $(0.011)$ & $(0.016)$ \\
Late payment & 0.037 & 0.027 & 0.010 & 0.014 \\
& $(0.034)$ & $(0.019)$ & $(0.031)$ & $(0.041)$ \\
Income fell & $0.025^{* * *}$ & $0.014^{* * *}$ & 0.006 & $0.071^{* * *}$ \\
& $(0.006)$ & $(0.002)$ & $(0.006)$ & $0.010)$ \\
Income increased & 0.016 & 0.002 & 0.014 & $\left(0.025^{*}\right.$ \\
& $(0.016)$ & $(0.007)$ & $(0.015)$ & $0.077^{* * *}$ \\
High school diploma & $0.028^{*}$ & 0.004 & 0.020 & $(0.021)$ \\
& $(0.016)$ & $(0.008)$ & $(0.015)$ & $0.121^{*}$ \\
Some college & -0.013 & 0.002 & -0.004 & $(0.068)$ \\
College degree or more & $(0.044)$ & $(0.023)$ & $(0.042)$ & $0.164^{* *}$ \\
& 0.020 & -0.002 & 0.033 & $(0.068)$ \\
2010q3 & $(0.047)$ & $(0.022)$ & $(0.046)$ & $\left(0.054^{* * *}\right.$ \\
& 0.017 & 0.001 & 0.025 & -0.011 \\
2010q4 & $(0.044)$ & $(0.021)$ & $(0.041)$ & $(0.026)$ \\
& 0.019 & -0.002 & 0.023 & -0.041 \\
2011q1 & $(0.022)$ & $(0.010)$ & $(0.021)$ & $(0.026)$ \\
& $0.041^{*}$ & 0.001 & $0.042^{*}$ & $-0.118^{* * *}$ \\
2011q2 & $(0.023)$ & $(0.010)$ & $(0.022)$ & $(0.023)$ \\
& -0.002 & -0.005 & -0.000 & $-0.095^{* * *}$ \\
2011q3 & $(0.021)$ & $(0.009)$ & $(0.020)$ & $(0.024)$ \\
2011q4 & -0.021 & -0.013 & -0.012 & $\left(0.0240^{* * *}\right.$ \\
& $(0.021)$ & $(0.009)$ & $(0.020)$ & 3518 \\
\hline$N$ & -0.016 & $-0.016^{* *}$ & -0.002 & $(0.021)$ \\
\hline
\end{tabular}

The excluded time period is 2010q1 through 2010q2.

Marginal effects, Standard errors in parentheses

${ }^{*} p<0.10,{ }^{* *} p<0.05,{ }^{* * *} p<0.01$

Source: Ohio State CFM 